\title{
School health services and community nutrition: a historical perspective
}

\author{
Juan Gondra Rezola ${ }^{1, *}$, Javier Santolaya ${ }^{2}$, Javier Orduna ${ }^{3}$ and Francisco Dehesa ${ }^{3}$ \\ ${ }^{1}$ Municipal Department of Public Health, Luis Briñas 18, 3rd Floor, E-48013 Bilbao, Spain: ${ }^{2}$ School Health \\ Programme, Bilbao Department of Public Health, Bilbao, Spain: ${ }^{3}$ Bilbao Municipal Department of Health and \\ Consumers' Affairs, Bilbao, Spain
}

\begin{abstract}
The Bilbao School Health Service was created at the beginning of the century with the aim of preventing transmittable diseases among children as well as improving nutrition. At that time such services were established in many other countries. Since then, according to evolving societal changes and emerging needs, the Service has reoriented its scope and structure towards the Health Promotion scheme.

Current tasks include health screening examinations and hygiene surveillance as well as preventive and health education programmes.
\end{abstract}

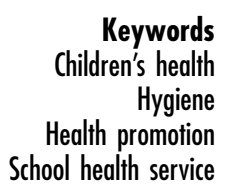

In 1900, the Spanish Director General for Health requested information from the Municipality of Bilbao regarding the causes for bearing the highest infant mortality rate in the country at that time. Dr Jose Maria Gorostiza, responsible for Public Health in the city, elaborated a report in this respect ${ }^{1}$. The topic for the 1901 Bilbao Flower Contest was 'Hygiene in Bilbao'. The winning paper approached the problem by analysing the causes and drafting a proposal for intervention ${ }^{2}$.

In this context the Bilbao School Health Service was created, in a similar way as other such services were created at the time, with the aim of improving children's health and well-being (Brussels, 1874; Paris, 1879; Leipzig, 1892; New York, 1897; Lisbon, 1902; Japan, 1903; London, 1908; etc.). The structure and plan of action in all of these cities followed like strategies, the same as in other towns in Europe (Newcastle Upon Tyne, Helsinforgs), South America (Buenos Aires) or North America $(\text { Boston })^{3}$.

The basis for action in the Bilbao Service was identifying the problems and underlying causes (diagnosis). Surveillance of hygiene conditions in every school was one of the components at this stage; individual physical examinations was another. Yearly reports highlighted the main causes of existing problems, including undernutrition among others.

In order to improve children's nutrition and health, three kinds of action were started: summer residential stays; school canteens, started in 1912; and supplemental feeding programmes ${ }^{4-7}$. School hygiene conditions were another priority. In order to achieve adequate conditions the following actions were implemented: surveillance of school infrastructure; ergonomic factors, such as suitability of school furniture, lighting, ventilation, heating and even characteristics of books and notebooks to ensure they were adequate for comfortable vision; regulation of school timing schedules, avoiding very long lessons and introducing recommendations for a 45-minute rest every 3 lecturing hours; and introduction of gymnastics as a respite for intellectual work and vision overload ${ }^{8-10}$.

Early diagnosis of children with infectious diseases and those with a high prevalence, such as nutrition disorders, vision impairment, epilepsy, etc., was a priority as well. Complementary action for Health and Hygiene Education was also very important.

Societal changes, which accompanied economic development, led also to changes in the programme according to the new situation in the 1970s and 1980s. Nowadays prevention actions are focused on chronic diseases such as cardiovascular disease or cancer, and trying to avoid injuries among children.

\section{Bilbao school health services}

Reorientation of existing services led to relevant changes in both programme objectives and organisational aspects. Nowadays, teachers, students, parents and health professionals work together in the context of Health Promotion $^{11}$. Programme objectives include early detection of health problems; supporting a healthy school environment; and enhancing the development of knowledge, attitudes and skills conducive to healthy lifestyles. In order to achieve these objectives the following activities are accomplished.

1. Health screening examinations - screening examinations take place at 4 years, 6 years, 10 years and 13 years. The screening protocol includes a vision test, a 
hearing capacity test, physical examination of the spine and limbs, measurement of height and weight. Children showing any abnormality are submitted to the corresponding paediatrician in the reference Primary Health Care Centre for further exploration and adequate treatment. The school health team ensures these children receive adequate treatment in the follow-up and provides support and links with social services when required. Special attention is given to children from disadvantaged groups, children suffering maltreatment in their families, those showing frequent school absenteeism, etc. School health services support the integration of these children and their families in the school life.

Additionally, school health services are responsible for immunisation programmes for older children and adolescents.

2. Surveillance of hygiene conditions in the school, ensuring that protocols to fight against insect and rodent plagues are applied according to regulations and adequate lighting, heating, ventilation and furniture are provided in every school to ensure a comfortable school life for students and teachers.

3. Epidemiological follow-up of transmittable disease spurs occurring in the school. This includes notification to competent authorities, implementation of adequate control measures in the school and provision of suitable information to the management, families and teachers. Special attention is paid to kitchen and lunchroom premises, toilets and gyms.

4. Follow-up of school meals service - the school team supports the Community Nutrition Unit in the School Meals Programme ${ }^{12}$ and liaises with catering companies and people responsible for the programme.

5. Implementation of Health Promotion and health education programmes - the school health team encourages and supports teachers in the implementation of health education programmes. They also develop specific actions targeted by parents and educators.

The Bilbao School Health Services continues to update its mission objectives and activities according to societal needs. Networking with the public, parent-teacher associations, education authorities and health authorities provides a valuable input; follow-up and evaluation support the changes required.

\section{References}

1 Gorostiza JM. Contestación a los Deseos Manifestados por el Llmo. Sr. Director General de Sanidad. Bilbao: Archivo Municipal Salud Escolar, 1901.

2 Gallastegui G, Pascual DP. La Higiene en Bilbao. Bilbao: Archivo Municipal, 1902.

3 Sancho Martínez F. La medicina escolar en el mundo. Rev. Española de Medicina e Higiene Escolar 1981; 35: 139-54.

4 Montero M. Crónicas de Bilbao y Vizcaya, IV. Bilbao: Ediciones, 1998; 70-6.

5 Cañellas C, Torán R. Escuela y sanidad: el movimiento higienista. Cuadernos de Pedagogía 1975; 4(Abr.): 1-23.

6 Jiménez-Morales R. Memoria Sobre la Organización de la Primera Colonia Escolar de Niños de Bilbao. Bilbao: Archivo Muncipal, 1898.

7 Puig Jofré E. Las colonias de vacaciones en Cataluña. Cuadernos de Pedagogía 1975; 7(July): 12-25.

8 Dufestel L. Higiene de las Escuelas y Guía práctica de su Médico Inspector, Saturnino Calleja. Madrid: Academia de Medicina, 1909; 275-307.

9 Burgerstein L. Higiene Escolar. Madrid: Editorial Labor, 1929; 109-22.

10 Hermosa-Elizondo JF. La inspección médica escolar en Bilbao. Doctoral thesis, Universidad Complutense de Madrid, Madrid, 1915; 12-23.

11 Ferrer Guardia F. La Escuela Moderna. Madrid: Ediciones Júcar, 1976; 100-1.

12 Aranceta J, Pérez Rodrigo C. Consumo de Alimentos y Estado Nutricional de la Población Escolar de Bilbao. Guias Alimentarias para la Población Escolar. Bilbao: Area de Salud y Consumo, Excmo, Ayuntamiento de Bilbao, 1996.

\section{Addendum}

In 2001, the Bilbao School Health Service is divided into six school health district areas. The following people are involved in the Bilbao School Health programme: C Abalia, I Aldamiz-Echevarria, I Amezaga, T Bonet, B Bustamante, J Caturla, V Celaya, B Domínguez, I López, G McGragh, E Marañon, A Mateos, I Olave, E Peral, A Saenz, L J. Santolaya, L Vidal, M Viladrich and A Vitorica. 